\title{
Alpine permafrost thawing during the Medieval Warm Period identified from cryogenic cave carbonates
}

\author{
M. Luetscher ${ }^{1}$, M. Borreguero ${ }^{2}$, G. E. Moseley ${ }^{1}$, C. Spötl ${ }^{1}$, and R. L. Edwards ${ }^{3}$ \\ ${ }^{1}$ Institute of Geology, University of Innsbruck, Innsbruck, Austria \\ ${ }^{2}$ Corcelles, Switzerland \\ ${ }^{3}$ Department of Geology and Geophysics, University of Minnesota, Minnesota, USA
}

Correspondence to: M. Luetscher (marc.luetscher@uibk.ac.at)

Received: 24 December 2012 - Published in The Cryosphere Discuss.: 30 January 2013

Revised: 28 March 2013 - Accepted: 31 May 2013 - Published: 9 July 2013

\begin{abstract}
Coarse crystalline cryogenic cave carbonates $\left(\mathrm{CCC}_{\text {coarse }}\right)$ dated to the last glacial period are common in central European caves and provide convincing evidence of palaeo-permafrost during this time. Little is known, however, about the exact nature of the environment in which $\mathrm{CCC}_{\text {coarse }}$ formed as no modern analogue setting is known. Here, we report the first findings of sub-recent, albeit inactive, $\mathrm{CCC}_{\text {coarse }}$ from a cave of the Western Alps which is located in the present-day permafrost zone. The globular shape and the presence of ubiquitous euhedral crystal terminations are comparable to previously reported aggregates from the last glacial period and strongly suggest that these aggregates formed subaqueously in pools lacking agitation. Furthermore, stable isotope values of mm-sized spheroids point to calcite precipitation in a closed system with respect to $\mathrm{CO}_{2}$, strongly supporting the hypothesis of a cryogenic origin associated with the freezing of water ponds. U-series analyses revealed three clusters of late Holocene calcite precipitation intervals between 2129 and 751 a b2k. These ages correlate with known periods of elevated summer temperatures, suggesting that warming and thawing of the frozen catchment above the cave allowed water infiltration into the karst system. The growth of $\mathrm{CCC}_{\text {coarse }}$ resulted from the re-freezing of this water in the still cold karst cavities.
\end{abstract}

\section{Introduction}

The distribution of alpine permafrost and its evolution in a changing climate is being extensively studied to identify potential hazards associated with instable debris slopes and rock-wall activity (e.g. Huggel et al., 2010; Fischer et al., 2012). Little is known, however, about the past evolution of permafrost (Harris et al., 2009; French, 2011; Stoffel and Huggel, 2012) and a better identification of freeze and thaw cycles could contribute to the interpretation of geomorphic and ecological responses to specific climatic events (e.g. Gutiérrez, 2005).

Caves represent unique environments to identify present and past cryogenic activity because they are connected to atmospheric processes but are well protected from surface erosion. Field evidence of palaeoglacial activity in the subsurface include frost shattering of cave ceilings, speleothem damage, ice attachments, cryoturbation and remobilization of cave sediments (eg. Kempe et al., 2009; Luetscher, 2013). While several of these features could also be caused by processes other than ice, a new class of carbonate deposits, cryogenic cave carbonates (CCC), has recently emerged as the most reliable indicator of (palaeo)glacial processes which can also be dated by U-series methods (Žák et al., 2004, 2008, 2012).

Cryogenic carbonates form by the segregation of solutes during the freezing of water (e.g. Shumskii, 1964; Killawee et al., 1998). Depending on the conditions during calcite precipitation a large range of shapes and sizes of CCC can be observed (Lacelle, 2007, Lacelle et al., 2009; Richter and Riechelmann 2008; Žák et al., 2008). Fine crystalline carbonate powder $\left(\mathrm{CCC}_{\text {fine }}\right)$, whose carbon isotopic composition exhibits large kinetic fractionation effects (Clark and Lauriol, 1992; Lacelle et al., 2006; Žák et al., 2008), is typically associated with rapid (seasonal) freezing under open system conditions (i.e. continuous exchange of $\mathrm{CO}_{2}$ with 


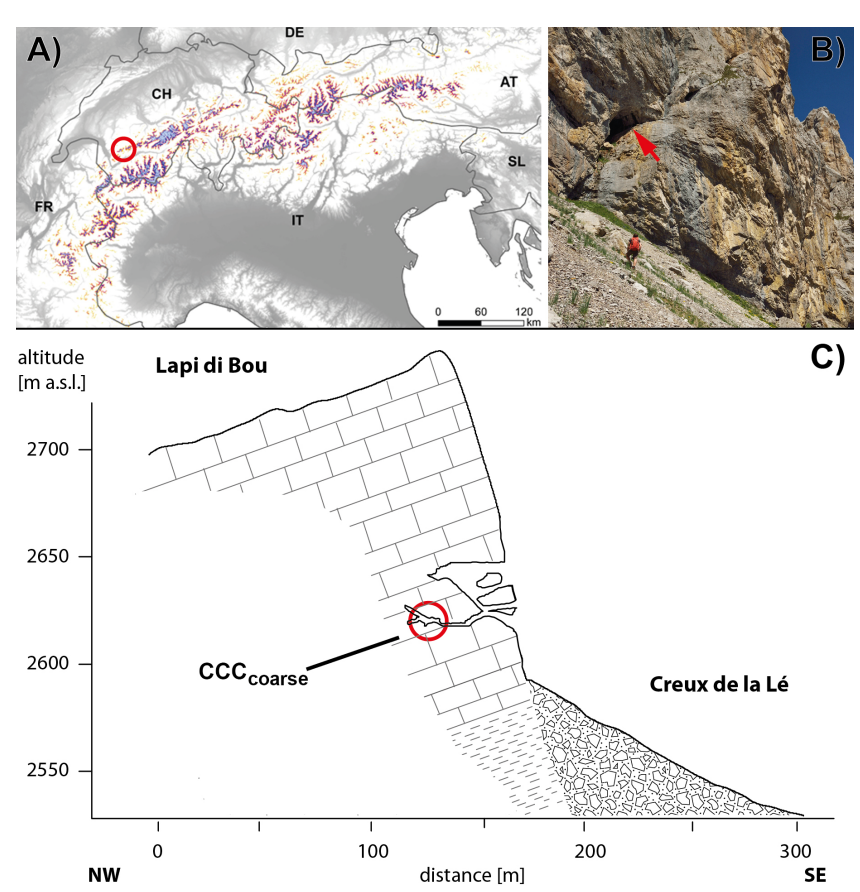

Fig. 1. (A) Site location (circle) plotted on the Alpine Permafrost Index Map (Boeckli et al., 2012); (B) Leclanché Cave entrance (arrow) in the Lé rock cliff; (C) vertical cross section of the Leclanché Cave system and location of the coarse crystalline cryogenic cave calcite $\left(\mathrm{CCC}_{\text {coarse }}\right)$ findings.

the cave atmosphere). In contrast, a negative correlation between $\delta^{18} \mathrm{O}$ and $\delta^{13} \mathrm{C}$ values indicates that precipitation of coarse crystalline cave carbonates $\left(\mathrm{CCC}_{\text {coarse }}\right)$ occurs essentially in a closed system (Žák et al., 2004). Whilst sitespecific $\delta^{13} \mathrm{C}$ offsets have been attributed to cave ventilation regimes before the water started to freeze (Richter et al., 2010), $\mathrm{CCC}_{\text {coarse }} \delta^{18} \mathrm{O}$ values typically depart from the parent solution (Žák et al., 2004). Richter et al. (2010) concluded that the formation of $\mathrm{CCC}_{\text {coarse }}$ most likely relates to the progressive freezing of water pools. The latter implies a steady heat exchange between the water and its surrounding environment, preferentially achieved in the homothermic zone of a permanently frozen karst system which is characterized by strongly reduced seasonal temperature fluctuations (Luetscher and Jeannin, 2004).

In contrast to $\mathrm{CCC}_{\text {fine, }}$, which has been reported from a number of alpine and arctic ice caves (Clark and Lauriol, 1992; Luetscher et al., 2007; Spötl, 2008; Richter et

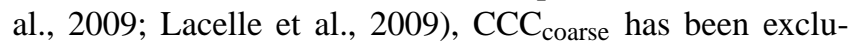
sively documented from presently ice-free Central European caves, located in former permafrost regions beyond the Pleistocene ice sheets (Žák et al., 2012). Yet, coarse crystalline glendonite aggregates have recently been reported from Scărişoara ice cave (Onac et al., 2011), suggesting that the spectrum of cryogenic cave carbonates is wider than previously assumed.
Applying ${ }^{230} \mathrm{Th} /{ }^{234} \mathrm{U}$ methods to determine the age of these $\mathrm{CCC}_{\text {coarse }}$ has recently opened a door to constrain the timing of permafrost occurrences in the Pleistocene (Žák et al., 2012). However, the lack of modern analogues has severely limited a profound understanding of the processes leading to $\mathrm{CCC}_{\text {coarse }}$ formation. This paper extends for the first time the record of $\mathrm{CCC}_{\text {coarse }}$ into the Holocene using samples from a partly deglaciated alpine cave located in the present-day permafrost zone. Here, we explore the palaeoclimate significance of these peculiar carbonate formations and demonstrate their potential to contribute to the reconstruction of alpine permafrost evolution during the Late Holocene.

\section{Study site}

Leclanché Cave is a $130 \mathrm{~m}$-long cave system located at $2620 \mathrm{~m}$ a.s.1. $\left(46^{\circ} 20^{\prime} 42^{\prime \prime} \mathrm{N}, 7^{\circ} 15^{\prime} 47^{\prime \prime} \mathrm{E}\right)$ in the Sanetsch area, western Swiss Alps (Borreguero et al., 2009). The cave opens with four individual entrances in a south-east facing rock cliff, at the base of the Schrattenkalk Formation, a Cretaceous platform limestone of the Helvetic realm (Wildhorn nappe, Mont-Gond unit; Badoux et al.,1959). The main cave passage, ca. $3 \mathrm{~m}$ wide and $1 \mathrm{~m}$ high, formed along a regional fault and is partly filled with massive congelation ice. In 2004, excavation of sediments obstructing the main conduit at $35 \mathrm{~m}$ from the cave entrance allowed speleologists to explore a $15 \times 3 \mathrm{~m}$ wide chamber in the rearmost part of the cave (Fig. 1). This chamber comprises abundant cryoclasts (i.e. angular rock fragments produced by frost shattering) covered by aggregates of $\mathrm{CCC}_{\text {coarse }}$ as well as fragments of flowstone (calcite coatings). A ca. $10 \mathrm{~m}^{3}$ perennial ice body was still present along the northern wall of the cave chamber in 2012, similar to what was observed during the first cave exploration in 2008 .

Cave air temperature recorded since 1998 at four different elevations (i.e. 2376, 2334, 2264 and $2258 \mathrm{~m}$ a.s.1.) at the nearby Grotte des Pingouins $\left(46^{\circ} 21^{\prime} 9^{\prime \prime} \mathrm{N}, 7^{\circ} 16^{\prime} 36^{\prime \prime} \mathrm{E}\right.$, 2333 ma.s.1.) were compared with sporadic (manual) temperature measurements from surrounding caves. These data locate the $0^{\circ} \mathrm{C}$ isotherm at $2260 \mathrm{ma}$.s.l., for a measured cave temperature gradient of $0.8^{\circ} \mathrm{C} 100 \mathrm{~m}^{-1}$ (Borreguero and Pahud, 2004), consistent with conspicuously dry cave conditions reflecting the scarcity of water infiltrating the karst permafrost. A reduced drainage may either shift the temperature gradient closer to the adiabatic lapse rate of dry air or/and sustain a somewhat higher contribution of the geothermal heat flux (e.g. Luetscher and Jeannin, 2004; Badino, 2010). In any case, we argue that this process is likely to affect the entire karst system and thus may also be representative of Leclanché Cave in which the temperature remains largely controlled by conductive heat exchanges with the surrounding environment (cf. Luetscher et al., 2008 or Obleitner and Spötl, 2011 for quantitative energy balances in ice caves). Still, well-developed conduits may drain 
substantial amounts of melt water in summer and thus locally transfer heat to the host rock. However, this water is subject to rapid refreezing when intersecting larger cave passages due to an increased rock-water exchange surface, eventually inhibiting further drainage.

The surface above Leclanché Cave is characterized by a denuded karst comprising widespread karrenfields and numerous cave entrances (Borreguero et al., 2009). The area receives ca. $1900 \mathrm{~mm}$ of annual precipitation, a large part of which falls as snow. Morphological observations suggest that small glaciers extended down to an elevation of ca. $2350 \mathrm{~m}$ a.s.l. on the Lapi di Bou during the Little Ice Age, but we found no evidence for the presence of glaciers at the cave entrance during the Holocene (Borreguero et al., 2009). Frost shattering is the dominant geomorphological process, forming large talus slopes at the base of the rock cliffs. Pioneer vegetation develops sporadically but is otherwise largely absent in the immediate cave surroundings. Alpine tundra vegetation is present up to ca. $2500 \mathrm{~m}$ a.s.l. and the local treeline, formed by Larix decidua and Pinus cembra (supra-subalpine belt) is currently located at ca. $2060 \mathrm{~m}$ a.s.l. (Berthel et al., 2012).

\section{Methods}

The $\mathrm{CCC}_{\text {coarse }}$ aggregates were examined using a binocular stereomicroscope, as well as in thin sections using transmitted-light (Leica M2 16A) and epifluorescence microscopy (Nikon Eclipse). Gold-coated samples were further examined by field-emission scanning electron microscopy (SEM, DSM 982 Gemini, Zeiss). Raman spectrometry was carried out using a Horiba Jobin-Yvon LabramHR800 spectrometer. Individual $\mathrm{CCC}_{\text {coarse }}$ aggregates were dissolved in $65 \%$ suprapure $\mathrm{HNO}_{3}$ and fluorescence properties were analysed using a Perkin-Elmer LS-55 spectrofluorometer. Results were interpreted from excitation-emission matrices obtained by collecting a series of 81 emission scans at $5 \mathrm{~nm}$ excitation wavelength intervals between $\lambda_{\text {ex }} 200$ and $600 \mathrm{~nm}$.

Seven individual $\mathrm{CCC}_{\text {coarse }}$ aggregates were prepared for ${ }^{230} \mathrm{Th} /{ }^{234} \mathrm{U}$ age determination. Chemical separation and multi-collector inductively coupled mass spectrometric (MCICPMS) measurement of $U$ and Th isotopic ratios were undertaken at the University of Minnesota using procedures similar to those described in Shen et al. (2012). Samples were pre-treated prior to chemical preparation in order to remove surface impurities from the $\mathrm{CCC}_{\text {coarse }}$ aggregates. Pretreatment included either leaching in a weak $2 \% \mathrm{HCl}$ solution for 2-3 min (LEC-b and -c) or cleaning ultrasonically in $15 \mathrm{M} \Omega$ water for $10 \mathrm{~min}$ (LEC-e to -g). Two samples were not pre-treated (LEC-a and -d). Resulting sub-samples for chemical separation and purification were between 17 and $104 \mathrm{mg}$.
The extent of detrital ${ }^{230} \mathrm{Th}$ contamination was estimated and corrected for by measurement of the long-lived chemically equivalent ${ }^{232} \mathrm{Th}$ and assuming a silicate bulk earth initial ${ }^{230} \mathrm{Th} /{ }^{232} \mathrm{Th}$ atomic ratio of $4.4 \pm 2.2 \times 10^{-6}$ (Wedepohl, 1995). Final ages are given as years before $2000 \mathrm{AD}$ (a b2k).

Water samples were collected from active drips at Leclanché Cave on 30 July 2012. The O isotope composition of water was determined by equilibration with $\mathrm{CO}_{2}$ using an online continuous flow system (Gasbench II) linked to a Delta ${ }^{\text {Plus }} \mathrm{XL}$ isotope ratio mass spectrometer. Calibration of the mass spectrometers was accomplished using VSMOW, GISP, and SLAP standards. The 1-sigma analytical errors on the $\delta^{18} \mathrm{O}$ is $0.09 \%$. CCC samples were analysed for $\delta^{18} \mathrm{O}$ and $\delta^{13} \mathrm{C}$ on the Delta ${ }^{\text {Plus }} \mathrm{XL}$ with an analytical precision $(1 \sigma)$ of $0.08 \%$ for $\delta^{18} \mathrm{O}$ and $0.06 \%$ for $\delta^{13} \mathrm{C}$ (Spötl and Vennemann, 2003), reported on the VPDB scale and calibrated against NBS19.

\section{Results}

\subsection{Petrography}

$\mathrm{CCC}_{\text {coarse }}$ occurs as loose aggregates on top of cryoclasts in the rearmost part of Leclanché Cave, spread over an area of between 2 and $4 \mathrm{~m}^{2}$ (Fig. 2a). No evidence of speleothem deposition postdating the formation of these aggregates was found. The amber-coloured samples, $1-4 \mathrm{~mm}$ in size $(2.9 \pm 0.9 \mathrm{~mm} ; n=62)$, form spheroids which sometimes collate into chains, up to $15 \mathrm{~mm}$ long (Fig. 2b-e). A rough estimate identified ca. 400 spheroids per $50 \mathrm{~cm}^{2}$, representing a total mass of ca. $15 \mathrm{~g}$ of secondary carbonate. Raman spectroscopy confirmed that calcite is the only mineral present although an earlier calcite generation, marked by a distinct whitish color, is commonly observed in the core of the spheroids. No evidence of detrital nuclei, however, was found in thin sections. The $\mathrm{CCC}_{\text {coarse }}$ show strong epifluorescence under the microscope and dissolved samples further exhibit fluorescence centres $\left(\lambda_{\text {ex }}: \lambda_{\text {em }}\right)$ at 250-280:400-460; 260-300:325-375, and 320-380:400-425 nm.

The globular shape and the presence of ubiquitous euhedral crystal terminations (Fig. 3a-e) strongly suggest that these aggregates formed subaqueously in pools lacking agitation. $\mathrm{CCC}_{\text {coarse }}$ aggregates consist of elongated calcite crystals which themselves comprise individual crystallites, giving rise to sweeping extinctions patterns under crosspolarized light. Some spheroids show a dent where crystal growth was apparently blocked giving rise to a conspicuously smoother surface (Fig. 3f). These concave parts (typically no more than one or two per spheroid) most likely represent the former interface to adjacent spheroids forming chains. 


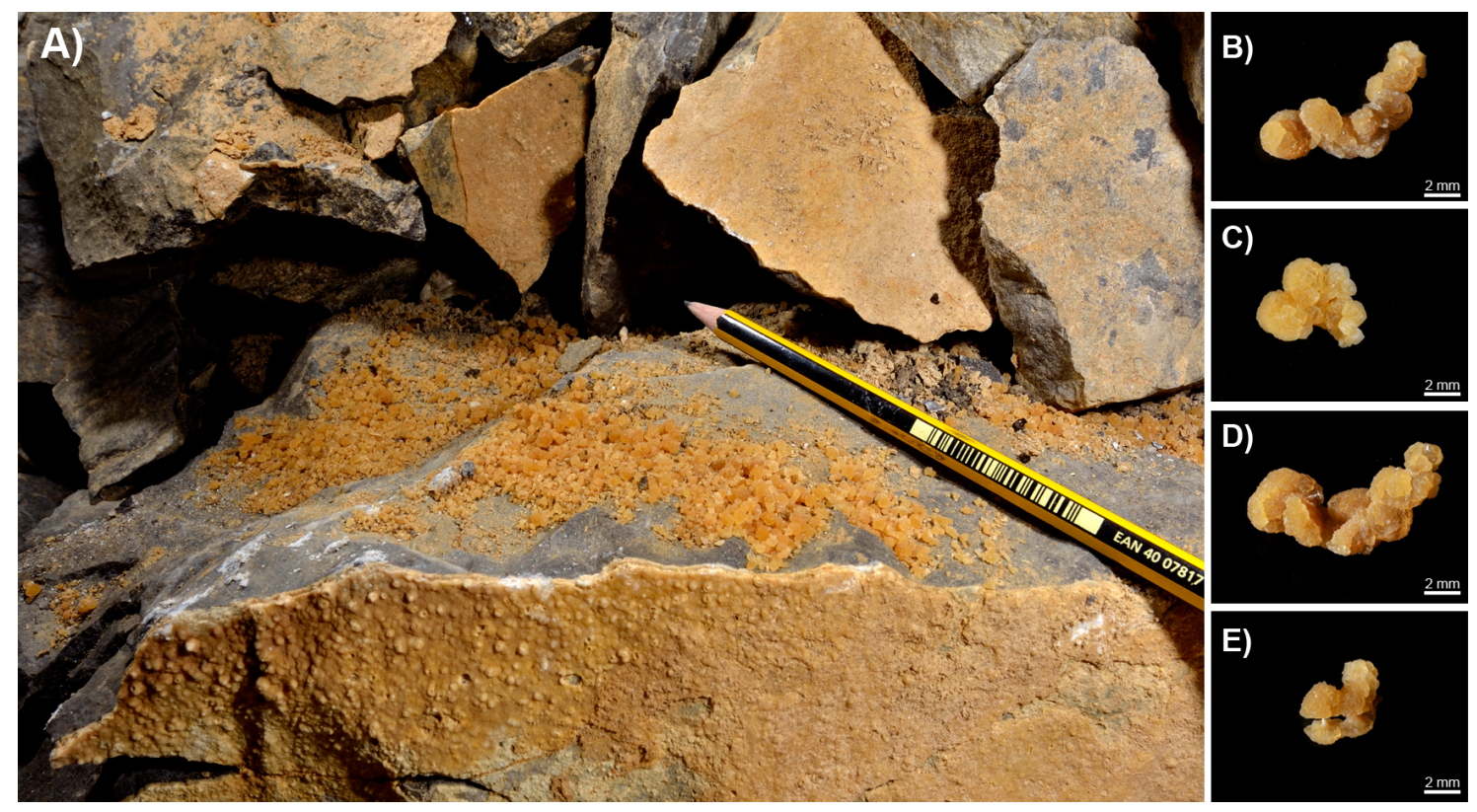

Fig. 2. Coarse crystalline cryogenic cave carbonate $\left(\mathrm{CCC}_{\text {coarse }}\right)$ observed in Leclanché Cave. The loose calcite crystal aggregates occur on the surface of cryoclasts, suggesting recent deposition. Calcite crusts coat several rock fragments, suggesting an earlier phase of vadose speleothem deposition under non-freezing conditions. Individual CCC aggregates, depicted on the right side, have spherical shapes and are amber-coloured. Photographs courtesy of R. Shone.

\subsection{Isotopic composition}

$\delta^{18} \mathrm{O}$ values of the remnant cave ice and active drip waters range between -10.9 and $-12.0 \%$, consistent with summer precipitation data at similar elevation in this region (Schürch et al., 2003). Stable isotope values of fossil stalagmites and flowstone from the Sanetsch area vary between -6.8 and $-10.2 \%$ ofor $\delta^{18} \mathrm{O}$. Elevated $\delta^{13} \mathrm{C}$ values in these speleothems, which range between -0.5 and $+4.5 \%$, reflect the lack of a soil cover in the hydrological catchment and possible kinetic fractionation effects. Non-equilibrium stable isotope fractionation is also typical for $\mathrm{CCC}_{\text {fine }}$ from this cave, with $\delta^{13} \mathrm{C}$ values reaching up to $+15.5 \%$ (Fig. 4).

In contrast to $\mathrm{CCC}_{\text {fine, }}$, bulk $\delta^{18} \mathrm{O}$ values of $\mathrm{CCC}_{\text {coarse }}$ range between -15.2 and $-17.5 \%$ and from -0.6 to $+2.2 \%$ of $\delta^{13} \mathrm{C}$ (Fig. 4 ). The two isotopes are strongly anticorrelated $\left(r^{2}=0.93 ; n=22\right)$. Transects milled at $250 \mu \mathrm{m}$ increments reveal a continuous enrichment in ${ }^{13} \mathrm{C}$ from the core to the spheroid rim along with a decrease in $\delta^{18} \mathrm{O}$ by nearly $2 \%$ (Fig. 5). Both trends follow a third-order power function consistent with a Rayleigh fractionation process and are attributed to progressive freezing of ponded water.

\subsection{U/Th dating}

Leclanché $\mathrm{CCC}_{\text {coarse }}$ are rich in $\mathrm{U}$, displaying ${ }^{238} \mathrm{U}$ concentrations between 1.9 and $2.3 \mu \mathrm{g} \mathrm{g}^{-1}$ (Table 1). Measured ${ }^{230} \mathrm{Th} /{ }^{232} \mathrm{Th}$ atomic ratios are less than $50 \times 10^{-6}$, indicating significant detrital ${ }^{230} \mathrm{Th}$ contamination. Coupled with low concentrations of authigenic ${ }^{230} \mathrm{Th}$, the precision of the final ages is significantly compromised, ranging between 7 and $12 \%$. Differences in pre-treatment methods appear to have had negligible effect on the final ages, with both leached and ultrasonically cleaned samples yielding coeval ages.

Results obtained from seven $\mathrm{CCC}_{\text {coarse }}$ samples yielded consistent clusters of ages ranging from 751 to 2129 a b2k (Table 1). Two coeval samples were deposited at $751 \pm 55$ and $823 \pm 58$ a b2k, whereas another four samples provide an average age of $1073 \pm 72$ a b2k $(1 \sigma)$. One sample suggests a significantly older age of $2129 \pm 235 \mathrm{a} \mathrm{b} 2 \mathrm{k}$.

\section{Discussion}

For the first time, sub-recent $\mathrm{CCC}_{\text {coarse }}$ were observed in a cave located in the alpine permafrost zone. The present-day cave temperature inferred from monitoring data in caves of the surrounding karst system suggests a mean annual air temperature of $-2.0 \pm 1.0^{\circ} \mathrm{C}$ at the study site. Despite the presence of substantial cave ice deposits leading to the occasional formation of fine crystalline cryogenic powders, no active $\mathrm{CCC}_{\text {coarse }}$ growth was observed in Leclanché Cave. The latter supports the hypothesis that the formation of $\mathrm{CCC}_{\text {coarse }}$ is a site-specific, possibly short-lived process associated with a particular cave environment. Preliminary investigations of $\mathrm{CCC}_{\text {coarse }}$ fluorescence properties further suggest that microbial activity was possibly present during calcite precipitation (cf. Birdwell and Summers Engel, 2010). 

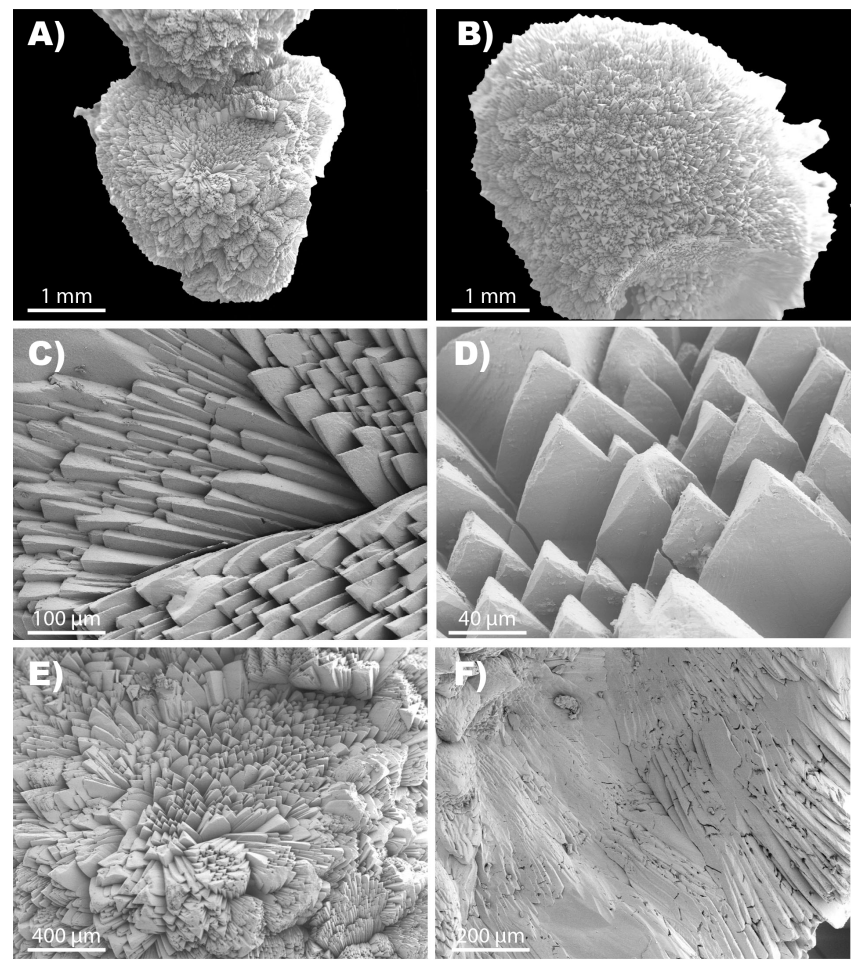

Fig. 3. SEM photomicrographs of coarse crystalline cryogenic cave carbonates $\left(\mathrm{CCC}_{\text {coarse }}\right)$ aggregates found in Leclanché Cave. Note the ubiquitous presence of euhedral (rhombohedral) crystal terminations except for local dents $(F)$ which represent the interface to an adjacent (now detached) spheroid.

A variety of morphological types of $\mathrm{CCC}_{\text {coarse }}$ have been described from former ice caves in Central Europe. Žák et al. (2012) grouped them into three broad categories: (i) individual crystals and random or organized aggregates, (ii) raftlike crystal aggregates, and (iii) fine to coarsely crystalline spherical/globular forms. Members of the first two types are conspicuously absent in Leclanché Cave where globular forms are the only type present. Hemispheric spheroids and in particular cupola-shaped forms with a hollow interior as described from the Malachitdom Cave in Germany (Erlemeyer et al., 1992; Schmidt, 1992; Richter and Riechelmann, 2008) are absent as well. Chain-like linked spheroids were likely more abundant in Leclanché Cave judging from the dents seen in several of the spheroids but apparently detached when the ice melted. Such aggregates have been reported from several Pleistocene ice caves in Central Europe (e.g. Richter and Riechelmann, 2008; Richter et al., 2010). However, the exclusive occurrence of rather uniform spheroids at Leclanché Cave contrasts with the typically more mixed appearance of $\mathrm{CCC}_{\text {coarse }}$ types in previously described Pleistocene permafrost caves. While the latter have been ascribed to several cycles of freezing and complete thawing of subsurface ice bodies (e.g., Richter et al., 2010), the samples from Leclanché Cave point to a rather common origin of the spheroids.

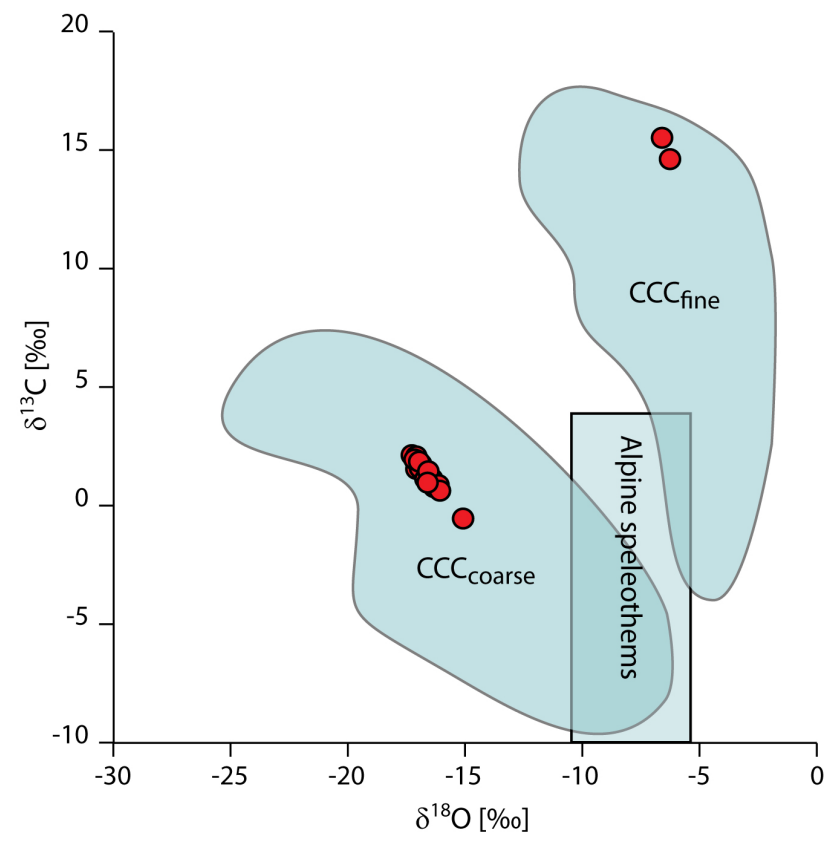

Fig. 4. Stable isotope data of cryogenic cave calcite (CCC) found in Leclanché Cave (red dots). Values from Central European caves (blue areas; Žák et al., 2012 and references therein) are shown together with the typical range of Alpine speleothems (unpublished data of the authors).

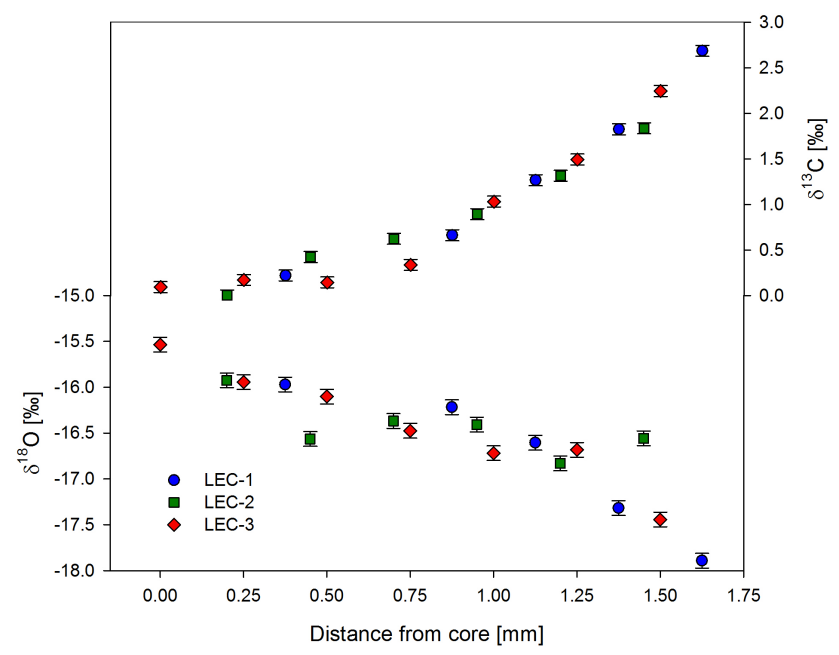

Fig. 5. Stable isotope composition across three individual coarse crystalline cryogenic cave carbonate $\left(\mathrm{CCC}_{\text {coarse }}\right)$ spheroids from Leclanché Cave. The marked negative correlation $\left(r^{2}=0.83\right)$ between $\delta^{13} \mathrm{C}$ and $\delta^{18} \mathrm{O}$ argues against kinetic fractionation effects and, accordingly, calcite precipitation is believed to have occurred close to isotopic equilibrium with the parent water.

Assuming a water alkalinity of $100 \pm 50 \mathrm{mg} \mathrm{L}^{-1}$ at $0^{\circ} \mathrm{C}$, simple carbonate mass balances confirm that the number of $\mathrm{CCC}_{\text {coarse }}$ found in Leclanché Cave is consistent with the freezing of individual water ponds, typically in the order 
Table 1. U and Th concentrations, isotopic activity ratios and ages of coarse crystalline cryogenic cave carbonates from Leclanché Cave, Switzerland.

\begin{tabular}{llllllllll}
\hline $\begin{array}{l}\text { Sample } \\
\text { Number }\end{array}$ & $\begin{array}{l}\text { Lab } \\
\text { Number }\end{array}$ & $\begin{array}{l}{ }^{238} \mathrm{U}^{\left[\mathrm{ng} \mathrm{g}^{-1}\right]} \\
{\left[{ }^{232} \mathrm{Th}\right.}\end{array}$ & $\begin{array}{l}{ }^{230} \mathrm{Th} /{ }^{232} \mathrm{Th} \\
\left(\text { atomic } \times 10^{-6}\right)\end{array}$ & $\begin{array}{l}\delta^{234} \mathrm{U}^{\mathrm{a}} \\
(\text { measured) }\end{array}$ & $\begin{array}{l}{ }^{230} \mathrm{Th} /{ }^{238} \mathrm{U} \\
\text { (activity) }\end{array}$ & $\begin{array}{l}{ }^{230} \mathrm{Th} \text { Age (a) } \\
\text { (uncorrected) }\end{array}$ & $\begin{array}{l}\delta^{234} \mathrm{U}_{\text {Initial }}^{\mathrm{b}} \\
\text { (corrected) }\end{array}$ & $\begin{array}{l}{ }^{230} \mathrm{Th} \mathrm{Age}(\mathrm{a} \mathrm{b2k})^{\mathrm{c}} \\
\text { (corrected ) }\end{array}$ \\
\hline LEC-a & GM48 & $2251 \pm 8$ & $7639 \pm 155$ & $49.1 \pm 1.0$ & $207.3 \pm 2.7$ & $0.0101 \pm 0.0001$ & $917 \pm 6$ & $207.8 \pm 2.7$ & $823 \pm 58$ \\
LEC-b & GM82 & $2042 \pm 2$ & $11415 \pm 229$ & $40.2 \pm 0.9$ & $208.4 \pm 1.7$ & $0.0136 \pm 0.0002$ & $1237 \pm 14$ & $209.0 \pm 1.7$ & $1090 \pm 96$ \\
LEC-c & GM83 & $1921 \pm 2$ & $8288 \pm 166$ & $47.0 \pm 1.2$ & $206.9 \pm 1.9$ & $0.0123 \pm 0.0002$ & $1117 \pm 16$ & $207.5 \pm 1.9$ & $1001 \pm 75$ \\
LEC-d & GM 143 & $2132 \pm 2$ & $29304 \pm 587$ & $32.5 \pm 0.7$ & $207.8 \pm 1.6$ & $0.0271 \pm 0.0002$ & $2472 \pm 22$ & $209.1 \pm 1.6$ & $2129 \pm 235$ \\
LEC-e & GM174 & $2321 \pm 2$ & $16417 \pm 329$ & $31.3 \pm 0.7$ & $209.3 \pm 1.7$ & $0.0134 \pm 0.0001$ & $1218 \pm 7$ & $209.9 \pm 1.7$ & $1036 \pm 121$ \\
LEC-f & GM 175 & $2186 \pm 2$ & $15476 \pm 310$ & $34.6 \pm 0.7$ & $208.6 \pm 1.6$ & $0.0149 \pm 0.0001$ & $1349 \pm 8$ & $209.3 \pm 1.6$ & $1166 \pm 121$ \\
LEC-g & GM 176 & $2327 \pm 2$ & $7352 \pm 147$ & $48.3 \pm 1.2$ & $209.3 \pm 1.7$ & $0.0093 \pm 0.0001$ & $839 \pm 12$ & $209.7 \pm 1.7$ & $751 \pm 55$ \\
\hline
\end{tabular}

Analytical errors are $2 \sigma$ of the mean: ${ }^{a} \delta^{234} U=\left(\left[{ }^{234} U / 238 U\right]\right.$ activity -1$) \times 1000$;

b $\delta^{234} \mathrm{U}_{\text {initial }}$ was calculated based on ${ }^{230}$ Th age $(T)$, i.e. $\delta^{234} \mathrm{U}_{\text {initial }}=\delta^{234} \mathrm{U}_{\text {measured }} \times \mathrm{e}^{\lambda 234 \times T}$.

Following decay constants were used: $\lambda^{230}=9.158 \times 10^{-6} \mathrm{a}^{-1}$ (Cheng et al., 2000); $\lambda^{234}=2.826 \times 10^{-6} \mathrm{a}^{-1}$ (Cheng et al., 2000$) ; \lambda^{238}=1.551 \times 10^{-10} \mathrm{a}^{-1}(\mathrm{Jaffey}$ et al., 1971). Corrected ${ }^{230} \mathrm{Th}$ ages assume an initial ${ }^{230} \mathrm{Th} /{ }^{232} \mathrm{Th}$ atomic ratio of $4.4 \pm 2.2 \times 10^{-6}$; i.e. values in secular equilibrium with a bulk Earth ${ }^{232} \mathrm{Th} /{ }^{238} \mathrm{U}$ value of 3.8 . The errors are arbitrarily assumed to be $50 \%$.

c a b2k stands for years before $2000 \mathrm{AD}$

$10^{-1} \mathrm{~m}^{3}$. At a permafrost temperature of $-2.0 \pm 1.0^{\circ} \mathrm{C}$, which is equivalent to the modern cave temperature, freezing of such water ponds likely takes place within a few days to several months, depending on the pool geometry. The relatively rapid freezing rate is difficult to reconcile with the compact, elongated columnar fabric of the $\mathrm{CCC}_{\text {coarse }}$ spheroids which points to rather slow crystallization rates. Therefore, we associate the formation of $\mathrm{CCC}_{\text {coarse }}$ with an initial water depth of at least ca. $50 \mathrm{~cm}$ which restrains heat exchanges between the pool and the cave atmosphere. The presence of multiple crystal generations further hints towards several thawing-freezing cycles, possibly associated with seasonal water inflows. ${ }^{230} \mathrm{Th} /{ }^{234} \mathrm{U}$ dating indicates that all spheroids formed in the Late Holocene. Moreover, six of the samples revealed ages ranging between $751 \pm 55$ and $1090 \pm 96$ a b2k, i.e. coeval with the Medieval Warm Period (MWP) characterized by elevated summer temperatures (Mangini et al., 2005; Büntgen et al., 2011; Fig. 6). Interestingly, one sample dated at $2129 \pm 235$ a b2k, falls within the Roman Warm Period which was also characterized by a succession of warm climate episodes (Büntgen et al., 2011) and reduced glacier extents (Holzhauser et al., 2005).

The formation of $\mathrm{CCC}_{\text {coarse }}$ during warm climate episodes affecting karst permafrost is consistent with observations of cave ice formation in the Sanetsch area (Borreguero et al., 2009). The rising temperature in the epikarst (i.e. surficial zone of a karst system) favours the infiltration of water which eventually refreezes within the cold cave environment. This process remains active until the conduit becomes completely obstructed by cave ice, preventing further infiltration. In contrast, large water inlets may advect sufficient energy to maintain a local thermal anomaly inhibiting the formation of cave ice. In the presence of irregular (concave) ice surfaces, some of this water may be temporarily confined in pools followed by progressive freezing. The solute segregation associated with this process will ultimately lead to the precipitation of $\mathrm{CCC}_{\text {coarse }}$ in the residual water. Depending on the initial

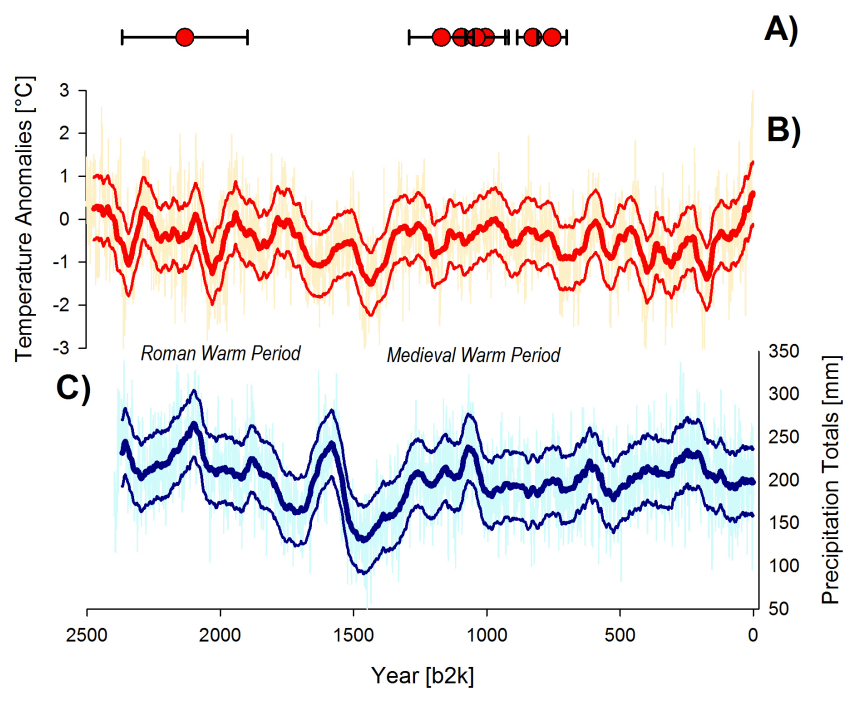

Fig. 6. (A) U-series ages of coarse crystalline cryogenic cave carbonates $\left(\mathrm{CCC}_{\text {coarse }}\right)$ from Leclanché Cave plotted against (B) JuneJuly-August temperature anomalies and (C) April-May-June precipitation totals over the last $2500 \mathrm{yr}$ reconstructed from Central European tree-rings (Büntgen et al., 2011).

carbonate saturation of the parent water and the associated freezing rate, a variety of $\mathrm{CCC}_{\text {coarse }}$ may be expected, underlined by their geochemical signatures.

The progressive freezing process is mirrored by the stable isotope composition across individual $\mathrm{CCC}_{\text {coarse }}$ spheroids (Fig. 5). $\delta^{13} \mathrm{C}$ values evolve along a fractionation path consistent with a closed system with respect to carbon, thus supporting the hypothesis of a shallow pool isolated from the cave atmosphere by a surficial ice layer. $\mathrm{CO}_{2}$ released during calcite precipitation escaped the system, either by entrapment in the ice as gas inclusions or by slow diffusion through the ice lid. Laboratory experiments showed that $\mathrm{CO}_{2}$ concentrations of occluded gas bubbles may reach up to 63 vol. \% 
(Killawee et al., 1998) but the resulting effect on carbon isotope fractionation is not fully understood yet. Richter et al. (2010) associated distinct $\delta^{13} \mathrm{C}$ values of $\mathrm{CCC}_{\text {coarse }}$ to the cave ventilation regime at the onset of freezing, but seasonal soil activity in the active layer above the cave could also play a role. Lacelle (2007), however, stated that the $\delta^{13} \mathrm{C}$ value of calcite during equilibrium freezing is not simply controlled by the initial composition of the water, but also by changing physical and geochemical conditions as freezing progresses. Regardless of the precise process, fractionation of carbon isotopes will proceed concurrently with the precipitation of CCC coarse (Žák et al., 2004).

The slow freezing of water under closed-system equilibrium conditions gives rise to progressive ${ }^{18} \mathrm{O}$ depletion in the residual water due to the preferential incorporation of the heavier isotope into the growing ice (O'Neil, 1968; Jouzel and Souchez, 1982; Souchez and Jouzel, 1984; Perşoiu et al., 2011). The highest $\delta^{18} \mathrm{O}$ values of calcite, therefore, likely reflect the composition of the initial water at the onset of calcite precipitation (Žák et al., 2012). The difference of nearly $7 \%$ o between inferred $\delta^{18} \mathrm{O}$ values (Kim and O'Neil, 1997 ) and the measured seepage water (ca. $-11 \%$ ), however, strongly suggests that the freezing of the water pond started some time before the precipitation of calcite.

\section{Conclusions}

Permafrost typically prevents the infiltration of water below the active layer. Although air and water flow in highpermeable karst systems may locally transfer sufficient heat to preserve a rudimentary drainage network, seepage and fracture flow is largely absent from frozen cave passages. In high alpine karst systems, thawing of ice-filled cavities and the subsequent flow of water through ice-free conduits is therefore a perceivable impact of a warming climate.

In contrast, the temporary obstruction of cave passages by ice and the slow freezing of water ponds in the homothermic zone of a karst system represent salient features of a frozen environment. Associated $\mathrm{CCC}_{\text {coarse }}$ therefore not only provides a clear indication of permafrost but also provide an archive for dating periods of melting in the hydrological catchment area.

This study demonstrates that $\mathrm{CCC}_{\text {coarse }}$ can be successfully used to identify and date Holocene permafrost thawing events. If verified in other caves, $\mathrm{CCC}_{\text {coarse }}$ has the potential to provide precise chronologies of past warm episodes in areas where palaeoenvironmental proxy data are scarce.
Acknowledgements. This study would not have been possible without the systematic explorations conducted by several generations of speleologists in the Sanetsch area. We are particularly indebted to G. Heiss and P. Tacchini who contributed to the discovery and careful documentation of Leclanché Cave. R. Shone is acknowledged for the photographs of the cryogenic cave calcites and K. Pfaller helped with SEM work. M. Luetscher acknowledges support by the Austrian Academy of Sciences (APART; project no. 715010). The careful reviews of K. Zak and an anonymous referee helped to improve the final version of the manuscript.

Edited by: S. Gruber

\section{References}

Badino G.: Underground meteorology - "What's the weather underground?", Acta Carsologica, 39, 427-448, 2010.

Badoux, H., Bonnard E. G., and Burri M.: Feuille St Léonard (35), notice explicative, Atlas géologique de la Suisse $1: 25000$, Kümerly and Frey, Berne, 1959.

Berthel, N., Schwörer, C., and Tinner, W.: Impact of Holocene climate changes on alpine and treeline vegetation at Sanetsch Pass, Bernese Alps, Switzerland, Rev. Palaeobot. Palyno., 174, 91100, 2012.

Birdwell, J. E. and Summers Engel, A.: Characterization of dissolved organic matter in cave and spring waters using UV-Vis absorbance and fluorescence spectroscopy, Org. Geochem., 41, 270-280, 2010.

Boeckli, L., Brenning, A., Gruber, S., and Noetzli, J.: Permafrost distribution in the European Alps: calculation and evaluation of an index map and summary statistics, The Cryosphere, 6, 807820, doi:10.5194/tc-6-807-2012, 2012.

Borreguero, M. and Pahud, A.: Mesures de température dans la grotte des Pingouins, évolution sur 5 ans, Cavernes, 2, 31-35, 2004.

Borreguero, M., Pahud, A., Favre, G., Heiss, G., Savoy, L., and Blant, M.: Lapi di Bou: Recherches et explorations spéléologiques 1974-2009, Cavernes, 70, 213 pp., 2009.

Büntgen, U., Tegel, W., Nicolussi, K., McCormick, M., Frank, D., Trouet, V., Kaplan, J., Herzig, F., Heussner, K.-U., Wanner, H., Luterbacher, J., and Esper, J.: 2500 years of European climate variability and human susceptibility, Science, 331, 578582, 2011.

Cheng, H., Edwards, R. L., Hoff, J., Gallup, C. D., Richards, D. A., and Asmerom, Y.: The half-lives of uranium-234 and thorium230, Chem. Geol., 169, 17-33, 2000.

Clark, I. D. and Lauriol, B.: Kinetic enrichment of stable isotopes in cryogenic calcites, Chem. Geol., 102, 217-228, 1992.

Erlemeyer, M., Hasenmayer, B., and Schudelski, A.: Das Höhlensystem Kreiselhalle-Malachitdom - ein bemerkenswerter Aufschluß für Höhlenminerale, in: Der Malachitdom, Ein Beispiel interdisziplinärer Höhlenforschung im Sauerland, 6989, Krefeld, Geol. Landesamt Nordrhein-Westfalen, 1992.

Fischer, L., Purves, R. S., Huggel, C., Noetzli, J., and Haeberli, $\mathrm{W} .:$ On the influence of topographic, geological and cryospheric factors on rock avalanches and rockfalls in high-mountain areas, Nat. Hazards Earth Syst. Sci., 12, 241-254, doi:10.5194/nhess12-241-2012, 2012. 
French, H.: Frozen sediments and previously-frozen sediments, in: Ice-marginal and Periglacial Processes and Sediments, edited by: Martini, I. P., French, H. M., and Perez Alberti, A., Geological Society, London, Special Publications, 354, 153-166, 2011.

Gutiérrez, M.: Climatic Geomorphology, Developments in Earth Surface Processes, 8, Elsevier, 760 pp., 2005.

Harris, C., Arenson, L. U., Christiansen, H. H., Etzelmüller, B., Frauenfelder, R., Gruber, S., Haeberli, W., Hauck, C., Hölzle, M., Humlum, O., Isaksen, K., Kääb, A., Kern-Lütschg, M. A., Lehning, M., Matsuoka, N., Murton, J. B., Nötzli, J., Phillips, M., Ross, N., Seppälä, M., Springman, S. M., and Vonder Mühll, D.: Permafrost and climate in Europe: Monitoring and modelling thermal, geomorphological and geotechnical responses, Earth Sci. Rev., 92, 117-171, 2009.

Holzhauser, H., Magny, M., and Zumbühl, H. J.: Glacier and lakelevel variations in west-central Europe over the last 3500 years, The Holocene, 15, 789-801, 2005.

Huggel, C., Salzmann, N., Allen, S., Caplan-Auerbach, J., Fischer, L., Haeberli, W., Larsen, C., Schneider, D., and Wessels, R.: Recent and future warm extreme events and high-mountain slope stability, Philos. T. R. Soc. A, 368, 2435-2459, 2010.

Jaffey, A. H., Flynn, K. F., Glendenin, L. E., Bentley, W. C., and Essling, A. M.: Precision measurement of half-lives and specific activities of ${ }^{235} \mathrm{U}$ and ${ }^{238} \mathrm{U}$, Phys. Rev., C4, 1889-1906, 1971.

Jouzel, J. and Souchez, R. A.: Melting-refreezing at the glacier sole and the isotopic composition of the ice, J. Glaciol., 28, 35-42, 1982.

Kempe, S., Bauer, I., and Dirks, H.: Glacial cave ice as the cause of wide-spread destruction of interglacial and interstadial speleothem generations in central Europe, in: Proceedings of the 15th International Congress of Speleology, edited by: White ,W. B., Kerrville, Texas, National Speleological Society, Inc., USA, 1026-1031, 2009.

Killawee, J. A., Fairchild, I. J., Tison, J.-L., Janssens, L., and Lorrain, R.: Segregation of solutes and gases in experimental freezing of dilute solutions: Implications for natural glacial systems, Geochim Cosmochim A., 62, 3637-3655, 1998.

Kim, S. T. and O'Neil, J. R.: Equilibrium and non-equilibrium oxygen isotope effects in synthetic carbonates, Geochim. Cosmochim. A., 61, 3461-3475, 1997.

Lacelle, D.: Environmental setting (micro) morphologies and stable C-O- isotope composition of cold climate carbonate precipitation - A review and evaluation of their potential as paleoclimatic proxies, Quaternary Sci. Rev., 26, 1670-1689, 2007.

Lacelle, D., Lauriol, B., and Clark, I. D.: Effect of chemical composition of water on the oxygen-18 and carbon-13 signature preserved in cryogenic carbonates, Arctic Canada: Implications in paleoclimatic studies, Chem. Geol., 234, 1-16, 2006.

Lacelle, D., Lauriol, B., and Clark, I. D.: Formation of seasonal ice bodies and associated cryogenic carbonates in Caverne de l'Ours, Québec, Canada: Kinetic isotope effects and pseudo-biogenic crystal structures, J. Cave Karst Stud., 71, 48-62, 2009.

Luetscher, M.: Glacial processes in caves, in: Treatise on Geomorphology, Schroder J. F., 6, San Diego, Academic Press, 258-266, 2013.

Luetscher, M. and Jeannin, P.-Y.: Temperature distribution in karst systems: the role of air and water fluxes, Terra Nova, 16, 344$350,2004$.
Luetscher, M., Bolius, D., Schwikowski, M., Schotterer, U., and Smart, P. L.: Comparison of techniques for dating of subsurface ice from Monlesi ice cave, Switzerland, J. Glaciol., 53, 374-384, 2007.

Luetscher M., Lismonde B., and Jeannin P-Y.: Heat exchanges in the heterothermic zone of a karst system: Monlesi cave, Swiss Jura Mountains, J. Geophys. Res., 113, F02025, doi:10.1029/2007JF000892, 2008.

Mangini, A., Spötl, C., and Verdes, P.: Reconstruction of temperature in the Central Alps during the past $2000 \mathrm{yr}$ from a $\delta^{18} \mathrm{O}$ stalagmite record, Earth Plan. Sci. Lett., 235, 741-751, 2005.

Onac, B. P., Wynn, J. G., and Citterio, M.: Ikaite in the Scărişoara Ice Cave (Romania): origin and significance, Geophys. Res. Abst., 13, EGU2011-5188, 2011.

O'Neil, J. R.: Hydrogen and oxygen isotope fractionation between ice and water, J. Phys. Chem., 72, 3683-3684, 1968.

Obleitner, F. and Spötl, C.: The mass and energy balance of ice within the Eisriesenwelt cave, Austria, The Cryosphere, 5, 245257, doi:10.5194/tc-5-245-2011, 2011.

Perşoiu, A., Onac, B. P., Wynn, J. G., Bojar, A-V., and Holmgren, K.: Stable isotope behavior during cave ice formation by water freezing in Scărişoara Ice Cave, Romania, J. Geophys. Res., 116, D02111, doi:10.1029/2010JD014477, 2011.

Richter, D. K. and Riechelmann, D. F. C.: Late Pleistocene cryogenic calcite spherolites from the Malachitdom Cave (NE Rhenish Slate, Mountains, Germany): origin, unusual internal structure and stable C-O isotope composition, Int. J. Speleology, 37, 119-129, 2008.

Richter, D. K., Voigt, S., and Neuser, R. D.: Kryogene Calcite unterschiedlicher Kristallform und Kathodolumineszenz aus der Glaseishöhle am Schneiber (Steinernes Meer/Nationalpark Berchtesgaden, Deutschland), Die Höhle, 60, 3-9, 2009.

Richter, D. K., Meissner, P., Immenhauser, A., Schulte, U., and Dorsten, I.: Cryogenic and non-cryogenic pool calcites indicating permafrost and non-permafrost periods: a case study from the Herbstlabyrinth-Advent Cave system (Germany), The Cryosphere, 4, 501-509, doi:10.5194/tc-4-501-2010, 2010.

Schmidt, F. X.: Mineralogische Besonderheiten aus dem Höhlensystem Kreiselhalle-Malachitdom, in: Der Malachitdom, Ein Beispiel interdisziplinärer Höhlenforschung im Sauerland, Krefeld, Geol. Landesamt Nordrhein-Westfalen, 91-104, 1992.

Schürch, M., Kozel, R., Schotterer, U., and Tripet, J.-P.: Observation of isotopes in the water cycle - the Swiss National Network (NISOT), Environ. Geol., 45, 1-11, doi:10.1007/s00254003-0843-9, 2003.

Shen, C.-C., Wu, C.-C., Cheng, H., Edwards, R.L., Hsieh, Y.-T., Gallet S., Chang, C.-C., Li, T.-Y., Lam, D. D., Kano, A., Hori, M., and Spötl, C.: High-precision and high-resolution carbonate ${ }^{230}$ Th dating by MC-ICP-MS with SEM protocols, Geochim. Cosmochim A., 99, 71-86, 2012.

Shumskii, P. A.: Principles of Structural Glaciology, Dover Publications, Inc., New York: 497 pp., 1964.

Souchez, R. A. and Jouzel, J.: On the isotopic composition in $\delta \mathrm{D}$ and $\delta^{18} \mathrm{O}$ of water and ice during freezing, J. Glaciol., 30, 369372, 1984. 
Spötl, C.: Kryogene Karbonate im Höhleneis der Eisriesenwelt, Die Höhle, 59, 26-36, 2008.

Spötl, C. and Vennemann, T.: Continuous-flow isotope ratio mass spectrometric analysis of carbonate minerals, Rapid Commun, Mass Spectrom, 17, 1004-1006, 2003.

Stoffel, M. and Huggel, C.: Effects of climate change on mass movements in mountain environments, Prog. Phys. Geog., 36, 421-439, 2012.

Wedepohl, K. H.: The composition of the continental-crust, Geochim. Cosmochim. A., 59, 1217-1232, 1995.
Žák, K., Urban, J., Cílek, V., and Hercman, H.: Cryogenic cave calcite from several Central European caves: age, carbon and oxygen isotopes and a genetic model, Chem. Geol., 206, 119-136, 2004.

Žák, K., Onac, B., and Perşoiu, A.: Cryogenic carbonates in cave environments: A review, Quatern. Int., 187, 84-96, 2008.

Žák, K., Richter, D. K., Filippi, M., Živor, R., Deininger, M., Mangini, A., and Scholz, D.: Coarsely crystalline cryogenic cave carbonate - a new archive to estimate the Last Glacial minimum permafrost depth in Central Europe, Clim. Past, 8, 1821-1837, doi:10.5194/cp-8-1821-2012, 2012. 